\title{
Early Detection and Control of Methicillin resistant Staphylococcus aureus Outbreak in an Intensive Care Unit
}

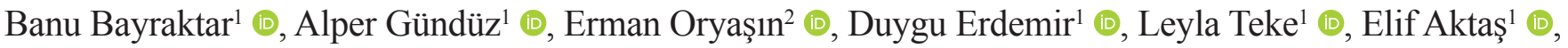 \\ Rıza Durmaz ${ }^{3}$ (D), Selma Şen ${ }^{1}$ (D), Nuray Uzun ${ }^{1}$ (D), Bülent Bozdoğan² (1)
}

${ }^{1}$ Department of Clinical Microbiology, University of Health Sciences Şişli Hamidiye Etfal Training and Research Hospital, İstanbul, Turkey

${ }^{2}$ REDPROM Ctr., Adnan Menderes University, Aydın, Turkey

${ }^{3}$ Microbiology Reference Laboratories, Public Health Agency of Turkey, Ankara, Turkey

Background: Although Methicillin resistant Staphylococcus aureus (MRSA) is one of the major pathogens of healthcare associated infections, we had only sporadic cases in our intensive care unit (ICU) for years.

Aims: To investigate the sudden increase in the number of MRSA cases in ICU.

Study design: Descriptive study.

Methods: From the $5^{\text {th }}$ December 2016 to $26^{\text {th }}$ January 2017, we detected 11 new MRSA cases in ICU. Screening of 73 ICU healthcare workers (HCWs) and screening of 13 patients was performed for outbreak investigation. Nine clinical isolates available in stocks and eight screening MRSA isolates were included in molecular studies. PFGE, spa-mecAmecC-PVL in-house multiplex PCR assay and spa typing, SCCmec typing were performed for all isolates. Sequence type of the representative strain was determined by Multi-Locus Sequence typing (MLST).
Results: All strains were mecA positive, PVL negative, and have the same antimicrobial susceptibility pattern except for two strains. All clinical, two patient screening and three nasal isolates of HCWs showed the same pulsotype, named clone A. The spa type of outbreak isolates is 030 and the SCCmec type is SCCmecIII; the MLST type of representative strain is ST239 (PFGE pulsotype A, ST239-SCCmecIII-t030). Unrelated three isolates had PFGE pulsotype B-SCCmecI-t030, PFGE pulsotype C-SCCmecIII-t459, PFGE pulsotype D-SCCmecIII.

Conclusion: Molecular typing techniques are the cornerstones for the investigation of outbreaks. Infection control measures, such as enhancing cleaning procedures, promoting hand hygiene, should be enforced in the ICU unit. All patients, including those who have already been discharged to other departments, must be put on contact isolation. HCWs carrying the MRSA strains could be offered decolonization.
Methicillin-resistant Staphylococcus aureus (MRSA) was described for the first time in1961, after the use of methicillin in 1959. MRSA is a causative agent of a broad spectrum of infectious diseases and considered as a frequent pathogen of health care-associated infections $(1,2)$. Methicillin resistance in $S$ aureus is encoded by mecA or mec $C$ genes that are carried on a mobile genetic element known as staphylococcal cassette chromosome (SCC) (1, 3 ). MRSA outbreaks are serious situations that can result in significant mortality and morbidity (4). Rapid diagnostic tests are needed to detect infections caused by MRSA strains and to limit the spread of these strains (3). Genotyping of outbreak strains to detect the possible source of the outbreak and immediate implementation of control measures are necessary. Frequently used molecular methods for typing purposes are pulsed-field gel electrophoresis
(PFGE), spa typing, SCCmec typing, and multilocus sequence typing (MLST).

In this study, we aimed to investigate new MRSA cases in the intensive care unit (ICU). We screened patients and health care workers (HCWs) and performed spa typing, PFGE, SCCmec typing, and MLST on MRSA strains to decide whether any transmission was occurring and measures of infection prevention were mandatory.

\section{MATERIALS AND METHODS}

\section{Ethical Considerations}

Ethics committee approval was received for this study from the Local Ethics Committe of Şişli Hamidiye Etfal Training and Research Hospital (date: 30.04.2019; number: 2377).

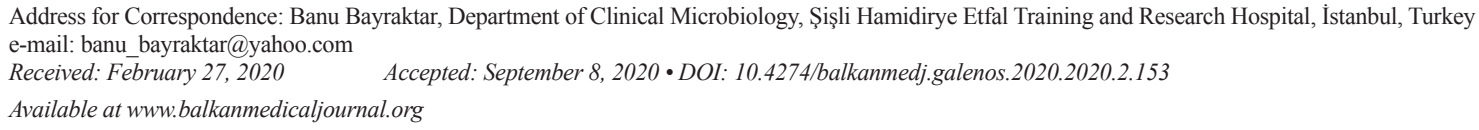


Outbreak description and bacterial isolates

From December 5, 2016, to January 26, 2017, we detected 11 new MRSA cases in the adult ICU. On December 20, 23, and 24, 2016, the Clinical Microbiology Department noticed 3 consecutive MRSA isolates, 2 from the blood and 1 from tracheal aspirate culture, having the same antibiotic susceptibility pattern belonging to 3 different patients in the adult ICU. We searched the Laboratory Information System for MRSA growths starting from October; we found 3 more isolates and 2 more cases who had already been discharged from the ICU to the neurology and general surgery wards. The first isolate was from a blood culture dated December 5 and belonged to a male patient who had a positive blood culture on December 20. We determined him as the index case. The index case was a morbidly obese patient hospitalized in the ICU because of respiratory failure owing to pneumonia and left ventricular dysfunction.

Nasal screening of 74 ICU HCWs and nasal, throat, axilla, groin, and rectum screening of 13 patients were performed for outbreak investigation. Identification and antimicrobial susceptibility test (AST) were done by MALDI-TOF MS (Bruker Daltonik GmbH, Bremen, Germany) and Phoenix100 ID/AST system (Becton Dickinson, Sparks, MD, USA), respectively.

A total of 9 clinical isolates available in stocks ( 7 blood, 1 tracheal aspirate, 1 abscess; 1 isolate per patient) and 8 screening MRSA isolates (5 HCWs and 3 patients) were included in molecular studies.

\section{Evaluation of mecA, mecC, spa, and $P V L$ genes by multiplex polymerase chain reaction}

In-house multiplex polymerase chain reaction (PCR) assay was performed as described by Stegger et al. (5). Instagene Matrix (Bio-Rad) was used for DNA extraction. Confirmation of methicillin resistance and identification of isolates were done by amplification of mecA/mecC genes and spa gene, respectively. We also searched for the Panton-Valentine leukocidin $(P V L)$ gene.

\section{spa typing}

spa gene amplicons were purified and sequenced. The open-source spa typing program at http://spatyper.fortinbras.us/ was used for spa sequence analysis.

\section{Pulsed-field gel electrophoresis}

PFGE typing of $S$ aureus strains was performed following the protocol of Yetkin et al. (6). Briefly, bacterial cells were embedded into low melting agarose including lysostaphin $(5 \mathrm{U} / \mathrm{mL})$. Cells in plugs were digested with proteinase K. After washing the plugs, genomic DNA in the plugs was restricted by $30 \mathrm{U}$ of SmaI (Promega Corporation, Durham, NC, USA) for 24 hours at $25^{\circ} \mathrm{C}$ in a water bath. DNA fragments were separated on $1 \%$ agarose gels run in $0.5 \times$ Tris-borate-ethylenediaminetetraacetic acid buffer using a CHEF-DR III system (Bio-Rad Laboratories, Nazareth, Belgium). The electrophoresis conditions were $14^{\circ} \mathrm{C}$ at $6 \mathrm{~V} / \mathrm{cm}^{2}$ for 20 hours. The initial and final switch times were 5.3 and 34.9 seconds, respectively. The gel was stained with ethidium bromide $(5 \mu \mathrm{g} / \mathrm{mL})$ for 20 minutes and destained with distilled water for 30 minutes. The DNA band profiles were visualized under ultraviolet light, photographed using a Gel Logic 2200 Imaging System (Kodak Co, Rochester, NY, USA), and analyzed by GelCompar software (version 7.0; Applied Maths, Sint-Martens-Latem, Belgium). A 1\% band tolerance was used for the comparison of DNA profiles. The clonal relationship among isolates was evaluated using the criteria of Tenover et al. (7).

\section{SCCmec typing}

$\mathrm{SCCmec}$ typing was performed using in-house multiplex PCR according to the procedure described by McClure-Warnier et al. (8). A total of 9 primer pairs were used for the screening of major SCCmec types and subtypes I to $\mathrm{V}$.

\section{Multilocus sequence typing}

The allelic profile of the outbreak MRSA strain was obtained by sequencing internal fragments of 7 house-keeping genes as described at http://saureus.mlst.net/misc/info.asp. (9): carbamate kinase (arc), Shikimate dehydrogenase (aro), Glycerol kinase (glp), Guanylate kinase (gmk), Phosphate acetyltransferase (pta), triosephosphate isomerase (tpi), and acetyl coenzyme A acetyltransferase (yqi). The DNA sequence of each allele analyzed using data analysis software at the http://saureus.mlst.net/sql/singlelocus.asp website and allele numbers of 7 amplicons were found out. By entering all allelic numbers of the strain in a program at the http:// saureus.mlst.net/sql/allelicprofilechoice.as website, the sequence type (ST) of the outbreak strain was determined.

\section{RESULTS}

Patient and HCW demographics, clonal characteristics, and antibiotic susceptibilities of MRSA isolates and molecular typing test results are presented in Table 1.

\section{Screening cultures}

Screening was performed in the ICU on December 24. Of the 13 patients, 5 were carrying MRSA strains, in multiple sites of their body; 2 of 5 sharing the same antibiotic susceptibility profile were shown to carry the outbreak strain by molecular typing methods (15\%). Of these 2 colonized patients, one carried the outbreak strain at nasal and groin sites, and the other one at the throat, nasal, groin, and rectum sites. Rectum-colonized patient was an 86-yearold man with a Fournier's gangrene; 18 of $73 \mathrm{HCWs}$ were $S$ aureus positive for their nasal swab cultures (10 methicillin-susceptible Staphylococcus aureus [MSSA]; 8 MRSA), and molecular typing was done for 5 MRSA sharing the same or similar antibiotic susceptibility pattern with outbreak strain (Table 1). Moreover, 3 of HCWs' nasal isolates were the outbreak strain (4\%).

\section{Antibiotic susceptibilities}

We performed the AST using the recommended methods and interpretation of the European Committee on Antimicrobial Susceptibility Testing. The outbreak strain was resistant to ciprofloxacin (CIP), levofloxacin (LEV), clindamycin (DA), erythromycin (E), tetracycline (TE), gentamicin $(\mathrm{GN})$, and tobramycin (TOB) and susceptible to trimethoprim-sulfamethoxazole (TMP-SXT), daptomycin (DPC), fusidic acid (FD), linezolid (LZD), and vancomycin (VA) except clinical isolate 8 and clinical isolate 9. Clinical isolate 8 and clinical isolate 9 were susceptible to DA, E, GN, and TOB.

\section{Decolonization of $\mathrm{HCWs}$}

All of the HCWs, except 1 pregnant nurse, were decolonized by TMP-SXT tablets $(800 / 160 \mathrm{mg}$ twice a day for 10 days). We checked the colonization status of HCWs 1 week after the completion of treatment. They were all cleared of the MRSA. 
TABLE 1. Patient and healthcare workers demographics, isolation sites, clonal characteristics, and antibiotic susceptibilities of MRSA isolate

\begin{tabular}{|c|c|c|c|c|c|c|c|c|c|c|c|c|c|c|c|c|c|c|c|c|c|c|}
\hline $\begin{array}{l}\text { Isolate } \\
\text { identifier }\end{array}$ & Age & Sex & Diagnosis & $\begin{array}{l}\text { Isolation } \\
\text { site }\end{array}$ & Therapy & Outcome & PFGE & $\begin{array}{l}\text { spa } \\
\text { type }\end{array}$ & $\begin{array}{l}\text { SCCmec } \\
\text { type }\end{array}$ & 茴 & 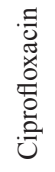 & 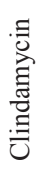 & 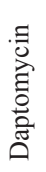 & 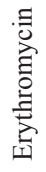 & 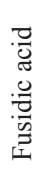 & 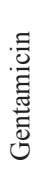 & 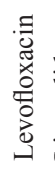 & 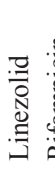 & 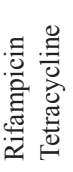 & 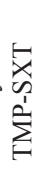 & 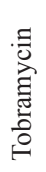 & 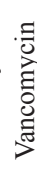 \\
\hline & & & Patients' isolates & & & & & & & & & & & & & & & & & & & \\
\hline CI-1 & 48 & M & Pneumonia & Blood & $\begin{array}{l}\text { PIP-TZP } 4.5 \text { g IV } \\
\text { TID; Daptomycin } \\
500 \text { mg IV daily }\end{array}$ & Died & A & t030 & Type III & $\mathrm{R}$ & $\mathrm{R}$ & $\mathrm{R}$ & $\mathrm{S}$ & $\mathrm{R}$ & $\mathrm{S}$ & $\mathrm{R}$ & $\mathrm{R}$ & $\mathrm{S}$ & $\mathrm{R} \mathrm{R}$ & $\mathrm{S}$ & $\mathrm{R}$ & $\mathrm{S}$ \\
\hline CI-2 & 79 & $\mathrm{~F}$ & $\begin{array}{c}\text { Cerebrovascular } \\
\text { disease }\end{array}$ & Trachea & $\begin{array}{l}\text { Linezolid } 600 \mathrm{mg} \\
\text { IV BID }\end{array}$ & Discharged & A & t030 & Type III & $\mathrm{R}$ & $\mathrm{R}$ & $\mathrm{R}$ & $\mathrm{S}$ & $\mathrm{R}$ & $\mathrm{S}$ & $\mathrm{R}$ & $\mathrm{R}$ & $\mathrm{S} \mathrm{I}$ & $\mathrm{R} \mathrm{R}$ & $\mathrm{S}$ & $\mathrm{R}$ & $\mathrm{S}$ \\
\hline CI-3 & 74 & $\mathrm{~F}$ & $\begin{array}{c}\text { Meninx benign } \\
\text { neoplasm }\end{array}$ & Trachea & $\begin{array}{l}\text { Vancomycin } 1 \mathrm{~g} \mathrm{IV} \\
\text { daily }\end{array}$ & Died & A & t030 & Type III & $\mathrm{R}$ & $\mathrm{R}$ & $\mathrm{R}$ & $\mathrm{S}$ & $\mathrm{R}$ & $\mathrm{S}$ & $\mathrm{R}$ & $\mathrm{R}$ & $\mathrm{S}$ & $\mathrm{R} R$ & $\mathrm{~S}$ & $\mathrm{R}$ & $\mathrm{S}$ \\
\hline CI-4 & 68 & M & Colon cancer & Blood & $\begin{array}{c}\text { Daptomycin } 350 \mathrm{mg} \\
\text { IV daily }\end{array}$ & Discharged & A & $\mathrm{t} 030$ & Type III & $\mathrm{R}$ & $\mathrm{R}$ & $\mathrm{R}$ & $\mathrm{S}$ & $\mathrm{R}$ & $\mathrm{S}$ & $\mathrm{R}$ & $\mathrm{R}$ & $\mathrm{S}$ & $\mathrm{R} \mathrm{R}$ & $\mathrm{S}$ & $\mathrm{R}$ & $\mathrm{S}$ \\
\hline CI-5 & 46 & $\mathrm{~F}$ & $\begin{array}{l}\text { Falling from } \\
\text { high }\end{array}$ & Trachea & $\begin{array}{c}\text { Tigecycline } 50 \mathrm{mg} \\
\text { IV BID; Meropenem } \\
1 \mathrm{~g} \text { IV TID }\end{array}$ & Discharged & A & t030 & Type III & $\mathrm{R}$ & $\mathrm{R}$ & $\mathrm{R}$ & $\mathrm{S}$ & $\mathrm{R}$ & $\mathrm{S}$ & $\mathrm{R}$ & $\mathrm{R}$ & $\mathrm{S}$ & $\mathrm{R} \mathrm{R}$ & $\mathrm{S}$ & $\mathrm{R}$ & $\mathrm{S}$ \\
\hline CI-6 & 49 & $\mathrm{~F}$ & Over cancer & Blood & $\begin{array}{l}\text { Vancomycin } 1 \mathrm{~g} \\
\text { IV BID }\end{array}$ & Discharged & A & t030 & Type III & $\mathrm{R}$ & $\mathrm{R}$ & $\mathrm{R}$ & $\mathrm{S}$ & $\mathrm{R}$ & $\mathrm{S}$ & $\mathrm{R}$ & $\mathrm{R}$ & $\mathrm{S}$ & $\mathrm{R} \mathrm{R}$ & $\mathrm{S}$ & $\mathrm{R}$ & $\mathrm{S}$ \\
\hline CI-7 & 88 & M & Colon cancer & Abscess & $\begin{array}{l}\text { Tigecycline } 50 \text { mg } \\
\text { IV BID; Meropen- } \\
\text { em } 1 \text { g IV TID }\end{array}$ & Discharged & A & t030 & Type III & $\mathrm{R}$ & $\mathrm{R}$ & $\mathrm{R}$ & $\mathrm{S}$ & $\mathrm{R}$ & $\mathrm{S}$ & $\mathrm{R}$ & $\mathrm{R}$ & $\mathrm{S}$ & $\mathrm{R} R$ & $\mathrm{~S}$ & $\mathrm{R}$ & $\mathrm{S}$ \\
\hline CI-8 & 23 & $\mathrm{M}$ & $\begin{array}{l}\text { Drug user, intox- } \\
\text { ication }\end{array}$ & Blood & $\begin{array}{c}\text { Tigecycline } 50 \mathrm{mg} \\
\text { IV BID; Meropenem } \\
1 \mathrm{~g} \text { IV TID }\end{array}$ & Discharged & A & t030 & Type I & $\mathrm{R}$ & $\mathrm{R}$ & $\mathrm{S}$ & $\mathrm{S}$ & $\mathrm{S}$ & $\mathrm{S}$ & $\mathrm{S}$ & $\mathrm{R}$ & $\mathrm{S}$ & $\mathrm{R} \mathrm{R}$ & $\mathrm{S}$ & $\mathrm{S}$ & $\mathrm{S}$ \\
\hline \multirow[t]{2}{*}{ CI-9 } & 86 & M & $\begin{array}{l}\text { Fournier's } \\
\text { gangrene }\end{array}$ & Blood & $\begin{array}{c}\text { Linezolid } 600 \mathrm{mg} \\
\text { BID }\end{array}$ & Died & A & t030 & Type III & $\mathrm{R}$ & $\mathrm{R}$ & $\mathrm{S}$ & $\mathrm{S}$ & $\mathrm{S}$ & $\mathrm{S}$ & $\mathrm{S}$ & $\mathrm{R}$ & $\mathrm{S}$ & $\mathrm{R} \mathrm{R}$ & $\mathrm{S}$ & $\mathrm{S}$ & $\mathrm{S}$ \\
\hline & & & $\begin{array}{l}\text { Screening cul- } \\
\text { tures isolates }\end{array}$ & & & & & & & & & & & & & & & & & & & \\
\hline Pt-S-1 & 63 & $\mathrm{~K}$ & $\begin{array}{l}\text { Cerebellar tu- } \\
\text { mor, epilepsy }\end{array}$ & $\begin{array}{l}\text { Throat, } \\
\text { nasal }\end{array}$ & $\begin{array}{c}\text { Vancomycin } 1 \mathrm{~g} \mathrm{IV} \\
\text { BID }\end{array}$ & Died & $\mathrm{C}$ & $\mathrm{t} 459$ & Type III & $\mathrm{R}$ & $\mathrm{R}$ & $\mathrm{R}$ & $\mathrm{S}$ & $\mathrm{R}$ & $\mathrm{S}$ & $\mathrm{R}$ & $\mathrm{R}$ & $\mathrm{S}$ & $\mathrm{R} R$ & $\mathrm{~S}$ & $\mathrm{R}$ & $\mathrm{S}$ \\
\hline Pt-S-2* & 74 & $\mathrm{~F}$ & $\begin{array}{l}\text { Meninx benign } \\
\text { neoplasm }\end{array}$ & $\begin{array}{l}\text { Nasal, } \\
\text { groin }\end{array}$ & $\begin{array}{l}\text { Vancomycin } \\
\text { daily }\end{array}$ & Died & A & t030 & Type III & $\mathrm{R}$ & $\mathrm{R}$ & $\mathrm{R}$ & $\mathrm{S}$ & $\mathrm{R}$ & $\mathrm{S}$ & $\mathrm{R}$ & $\mathrm{R}$ & $\mathrm{S}$ & $\mathrm{R} R$ & $\mathrm{~S}$ & $\mathrm{R}$ & $\mathrm{S}$ \\
\hline Pt-S-3** & 86 & M & $\begin{array}{l}\text { Fournier's } \\
\text { gangrene }\end{array}$ & $\begin{array}{l}\text { Throat, } \\
\text { nasal, } \\
\text { groin, } \\
\text { rectum }\end{array}$ & $\begin{array}{l}\text { Linezolid } 600 \mathrm{mg} \\
\text { IV BID }\end{array}$ & Died & A & t030 & Type III & $\mathrm{R}$ & $\mathrm{R}$ & $\mathrm{R}$ & $\mathrm{S}$ & $\mathrm{R}$ & $\mathrm{S}$ & $\mathrm{R}$ & $\mathrm{R}$ & $\mathrm{S}$ & $\mathrm{R} \mathrm{R}$ & $\mathrm{S}$ & $\mathrm{R}$ & $\mathrm{S}$ \\
\hline HCW-1 & 44 & $\mathrm{E}$ & & Nasal & $\begin{array}{c}\text { TMP-SXT 160/800 } \\
\text { mg PO BID }\end{array}$ & & A & t030 & Type III & $\mathrm{R}$ & $\mathrm{R}$ & $\mathrm{R}$ & $\mathrm{S}$ & $\mathrm{R}$ & $\mathrm{S}$ & $\mathrm{R}$ & $\mathrm{R}$ & S I & $\mathrm{R} R$ & $\mathrm{~S}$ & $\mathrm{R}$ & $\mathrm{S}$ \\
\hline HCW-2 & 23 & $\mathrm{E}$ & & Nasal & $\begin{array}{c}\text { TMP-SXT 160/800 } \\
\text { mg PO BID }\end{array}$ & & $\mathrm{D}$ & ND & Type III & $\mathrm{R}$ & $\mathrm{R}$ & $\mathrm{R}$ & $\mathrm{S}$ & $\mathrm{R}$ & $\mathrm{S}$ & $\mathrm{R}$ & $\mathrm{R}$ & $\mathrm{S}$ & $\mathrm{R} \mathrm{R}$ & $\mathrm{S}$ & $\mathrm{R}$ & $\mathrm{S}$ \\
\hline HCW-3 & 28 & $\mathrm{E}$ & & Nasal & $\begin{array}{c}\text { TMP-SXT 160/800 } \\
\text { mg PO BID }\end{array}$ & & A & $\mathrm{t} 030$ & Type V & $\mathrm{R}$ & $\mathrm{R}$ & $\mathrm{R}$ & $\mathrm{S}$ & $\mathrm{R}$ & $\mathrm{S}$ & $\mathrm{R}$ & $\mathrm{R}$ & $\mathrm{S}$ & $\mathrm{R} \mathrm{R}$ & $\mathrm{S}$ & $\mathrm{R}$ & $\mathrm{S}$ \\
\hline HCW-4 & 30 & $\mathrm{~K}$ & & Nasal & Not decolonized & & A & t030 & Type III & $\mathrm{R}$ & $\mathrm{R}$ & $\mathrm{S}$ & $\mathrm{S}$ & $\mathrm{S}$ & $\mathrm{S}$ & $\mathrm{S}$ & $\mathrm{R}$ & $\mathrm{S} \mathrm{I}$ & $\mathrm{R} R$ & $\mathrm{~S}$ & $\mathrm{~S}$ & $\mathrm{~S}$ \\
\hline HCW-5 & 24 & $\mathrm{~K}$ & & Nasal & $\begin{array}{c}\text { TMP-SXT 160/800 } \\
\text { mg PO BID }\end{array}$ & & B & t030 & Type I & $\mathrm{R}$ & $\mathrm{R}$ & $\mathrm{S}$ & $\mathrm{S}$ & $\mathrm{S}$ & $\mathrm{S}$ & $\mathrm{S}$ & $\mathrm{R}$ & $\mathrm{S}$ & $\mathrm{R} R$ & $\mathrm{~S}$ & $\mathrm{~S}$ & $\mathrm{~S}$ \\
\hline
\end{tabular}

Evaluation of mecA-mecC-SPAPVL multiplex PCR All strains were positive for the $m e c A$ gene and negative for the $P V L$ gene.

\section{Molecular typing}

All clinical isolates and 2 patient screening and 3 nasal isolates of HCWs showed the same PFGE pulsotype (PT) that was named 

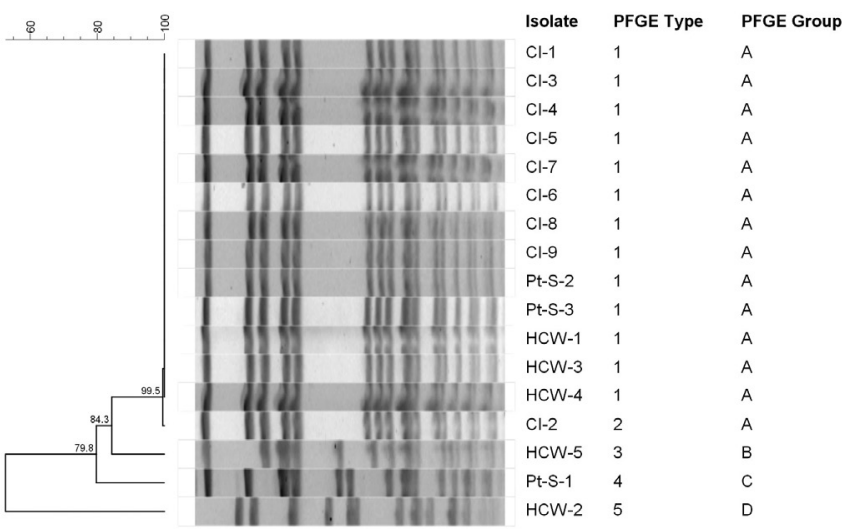

FIG. 1. PFGE smal restriction patterns of MRSA clinical isolates clone A Lanes 1 and 15, Salmonella braenderup molecular size marker; lanes 4 to 7 , $\mathrm{Cl}-1, \mathrm{Cl}-2, \mathrm{Cl}-3$, and $\mathrm{Cl}-4$; and lanes 9 to $13, \mathrm{Cl}-5, \mathrm{Cl}-6, \mathrm{Cl}-8, \mathrm{Cl}-7$, and $\mathrm{Cl}-9$, respectively; lanes 2 to 4 and 14 , Cls that were unrelated to the outbreak; lane 8, empty

Cl: clinical isolate, MRSA: methicillin-resistant Staphylococcus aureus, PFGF: pulsed-field gel electrophoresis

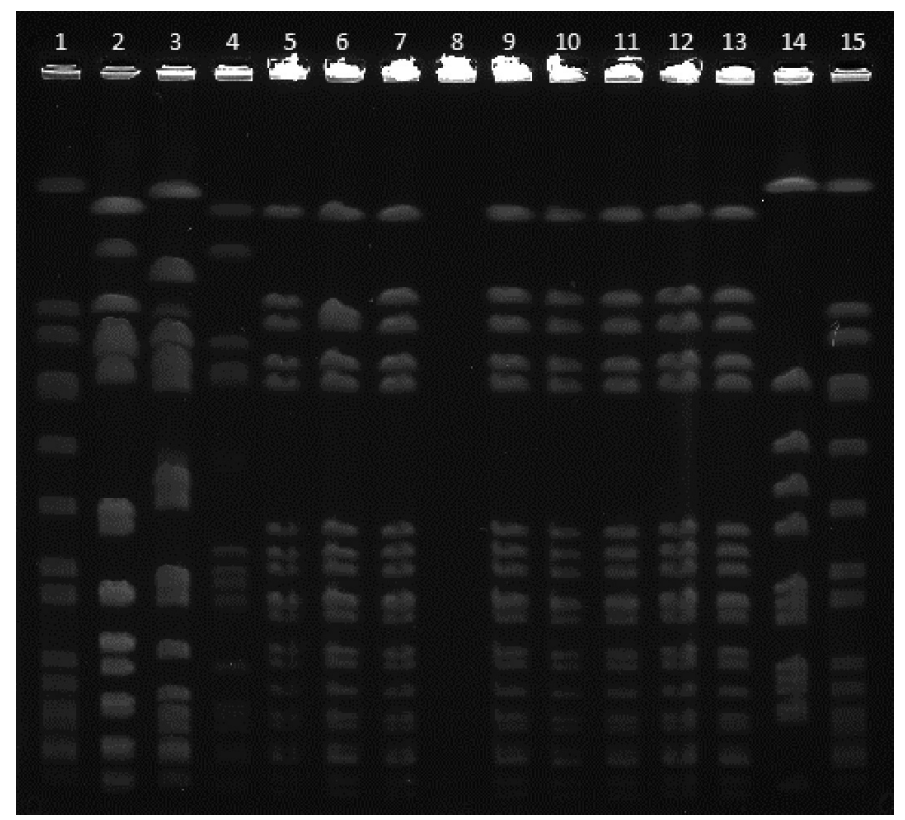

FIG. 2. PFGE dendrogram showing different PTs seen over the duration of outbreak (A to D). PT A belongs to outbreak strain PFGE: pulsed-field gel electrophoresis, PT: pulsotype

as clone A (Figure 1). The spa ST of these isolates was t030, and the SCCmec type was SCCmecIII. The MLST result was ST239. Clinical isolate 8 and HCW-3 have different SCCmec types, SCC$m e c \mathrm{I}$ and $\mathrm{SCCmecV}$, respectively. Unrelated 3 isolates had PFGE PT B-SCCmecI-t030, PFGE PT C-SCCmecIII-t459, and PFGE PT D-SCCmecIII (Figure 2).

\section{DISCUSSION}

In this study, we report our experience about the MRSA outbreak in an adult ICU. The outbreak was noticed in the middle of December
2016; by that time, 4 patients had already been discharged from the ICU to other clinical wards. We assume that our index case was a male patient who stayed in the ICU for more than a month. Few HCWs were colonized with the outbreak strain, and we assume HCWs might have transmitted the outbreak strain to other patients during the medical care as reported in the literature before (10).

To interrupt the MRSA transmission, various infection control measures were established immediately. Nasal screening of HCWs and nasal, throat, axilla, groin, and rectal screening of ICU patients were performed (11). All of HCWs carrying the MRSA strains except 1 pregnant employee were treated with co-trimoxazole as a decolonization procedure because mupirocin ointment for nasal usage is not available in the market in our country (12). We put our infected and colonized patients in contact isolation, including those who had already been discharged to other wards (13). Infection control nurses gave educational sessions to HCWs on promoting hand hygiene and enhancing cleaning procedures. We screened patients a month later and there were still patients colonized with the outbreak strain, but no new MRSA cases occurred. Therefore, we declared the outbreak was over and decided to follow up on the situation. Identification of an outbreak is usually based on molecular typing, which is a significant tool in infection control. Molecular typing methods show the nosocomial transmission of the successful clone and elucidate its transmission routes and sources in an outbreak setting (14). Different molecular methods are available for typing of $S$ aureus isolates, including PFGE, multilocus variable number of tandem repeat analysis, SCCmec typing, spa typing, MLST, and full-genome sequencing $(1,3,15)$. PFGE is still accepted as the "gold standard" for molecular typing of MRSA, and SmaI is the enzyme of the choice for macrorestriction (16). The major drawback of PFGE is the insufficient comparability of results between laboratories, which might be overcome by using standardized protocols nationally $(2,16)$. In contrast, results of MLST are comparable between laboratories, but its routine use in infection control is restricted by high cost, labor intensity, and availability of DNA sequencer (16). Recently, it has been reported that spa typing and MLST typing have comparable performance in a macroepidemiologic study (15). Moreover, spa typing has a higher discriminatory power over MLST, so 1 ST type can harbor several spa types, but they remain within the same clonal complex (17). In this study, we used several typing methods, PFGE, SCCmec typing, spa typing, and MLST, simultaneously, for the characterization of the outbreak strain. The outbreak isolates showed the same PFGE PT named as clone A and were ST239-SCCmecIII-t030 strains. ST239-SCCmecIII-t030 has previously been reported as the most frequent hospital-associated (HA) MRSA clone in Turkey (18) and named as TR09. Other studies from Turkey also reported the dominance of MLST ST239 and spa type t030 (19-21) characterized MRSA clones. Oksuz et al. (21) found Vienna/Hungarian/Brazilian clone (ST239-MRSA-III) as the most prevalent clone (53.9\%) in a university hospital for more than 5 years, and the rest of the MRSA clones were largely diverse. Geographic distribution of major HA MRSA clones is known worldwide, but sometimes shifts of these MRSA clones have occured over time in countries, in a region, or even in a single hospital (22). MRSA evolved from MSSA in 1961 by the acquisition of SCCmec (1). Since then, a limited number of clones with a certain genetic background and SCCmec type have 
spread worldwide (22). MRSA ST239 lineage is a globally disseminated HA MRSA consisting of more than 5 clades, such as Asia, North America, South America, Europe, and Australia (23). ST239 is a successful clone in terms of infiltration and adaptation in hospital settings (24). Several studies are being conducted to identify the reasons behind this success. Recently, Hong et al. (24) reported that a higher expression of staphylococcal protein A (SpA) in HA MRSA ST239 helps for durable colonization and immune evasion of the clone. Furthermore, they stipulated that $\mathrm{SpA}$ may be a significant factor for the adaptation and persistence of the ST239 clone in hospital environments. Moreover, 2 colonization factors, sasX protein first described in ST239 clone during an outbreak in London and arginine catabolic mobile element (ACME), were found to be associated with the epidemiologic success of the MRSA. ACME was first described in CA-MRSA USA300 and has spread horizontally to HA sequence types such as ST5 and ST239 $(25,26)$. Finally, enteric carriage of HA MRSA has been shown for ST228 and was considered responsible for maintaining a long-term outbreak in a tertiary hospital (27). In our patient group, we found out that 1 patient had enteric colonization with the outbreak strain. However, he was not the index case.

The outbreak strain was resistant to CIP, LEV, DA, E, TE, GN, and TOB and susceptible to TMP-SXT, DPC, FD, LZD, and VA. This resistance pattern was very similar to that indicated in previous reports $(21,23,28)$. PVL was not detected on the outbreak strain.

In conclusion, we described an MRSA outbreak in the ICU owing to the clonal spread of the specific strain. Infection control measures were put in practice immediately upon the detection of clustering. Through the microbiologic typing methods, outbreak strain was described in detail and the index case was identified. The outbreak was successfully controlled through universal contact precautions and treatment of infected patients and decolonization of HCWs for nasal carriage.

Ethics Committee Approval: Ethics committee approval was received for this study from the Local Ethics Committe of Şişli Hamidiye Etfal Training and Research Hospital (date: 30.04.2019; number: 2377).

Patient Consent for Publication: The authors did not take any informed consent from patient due to study design.

\section{Data-sharing Statement: N/A.}

Author Contributions: Concept - B.Bayraktar.; Design - B.Bayraktar, A.G.; Supervision - B.Bayraktar, B.Bozdağan.; Resources - B.Bayraktar, B.Bozdağan, R.D., N.U.; Materials - B.Bayraktar, B.Bozdağan, R.D.; Data Collection and/or Processing - L.T., E.O., S.Ş., D.E.; Analysis and/or Interpretation - B.Bayraktar, E.O., A.G., E.A.; Literature Search B.Bayraktar, L.T.; Writing Manuscript - B.Bayraktar.; Critical Review - B.Bayraktar, A.G.

Conflict of Interest: The authors have no conflicts of interest to declare.

Funding: The authors declared that this study had received no financial support. All expenses belong to the authors.

\section{REFERENCES}

1. Liu J, Chen D, Peters BM, Li L, Li B, Xu Z. et al. Staphylococcal chromosomal cassettes mec (SCCmec): A mobile genetic element in methicillin-resistant Staphylococcus aureus. Microb Pathog 2016;101:56-67. [Crossref]

2. Simor AE, Ofner-Agostini M, Bryce E, McGeer A, Paton S, Mulvey MR, et al. Laboratory characterization of methicillin-resistant Staphylococcus aureus in Canadian hospitals: Results of 5 years of National Surveillance, 1995-1999. J Infect Dis 2002;186:652-60. [Crossref]
3. te Witt R, van Belkum A, van Leeuwen WB. Molecular diagnostics and genotyping of MRSA: An update. Expert Rev Mol Diagn 2010;10:375-80. [Crossref]

4. Khan A, Lampitoc M, Slaripour M, McKernan P, Devli R, Muller MP. Rapid control of amethicillin reistant Staphylococcus aureus (MRSA) outbreak in a medical surgical intensive care unit (ICU). Can J Infect Control 2009;24:12-6.

5. Stegger M, Andersen PS, Kearns A, Pichon B, Holmes MA, Edwards G, et al. Rapid detection, differentiation and typing of methicillin-resistant Staphylococcus aureus harbouring either mecA or the new mecA homologue mecA (LGA251). Clin Microbiol Infect 2012;18:395-400. [Crossref]

6. Yetkin GKÇ, Durmaz B, Durmaz R, Çizmeci Z, İşeri L. Molecular typing of methicillin-resistant Staphylococcus aureus isolated from bloodstream infections in a university hospital. Turk J Med Sci 2009;39:959-68.

7. Tenover FC, Arbeit RD, Goering RV. How to select and interpret molecular strain typing methods for epidemiological studies of bacterial infections: A review for healthcare epidemiologists. Molecular Typing Working Group of the Society for Healthcare Epidemiology of America. Infect Control Hosp Epidemiol 1997;18:426-39. [Crossref]

8. McClure-Warnier JA, Conly JM, Zhang K. Multiplex PCR assay for typing of staphylococcal cassette chromosome mec types I to V in methicillin resistant Staphylococcus aureus. J Vis Exp 2013; (79):50779. doi: 10.3791/50779. [Crossref]

9. Enright MC, Day NP, Davies CE, Peacock SJ, Spratt BG. Multilocus sequence typing for characterization of methicillin-resistant and methicillin-susceptible clones of Staphylococcus aureus. J Clin Microbiol 2000;38:1008-15. [Crossref]

10. Stock NK, Petráš P, Melter O, Kapounová G, Vopalková P, Kubele J, et al. Importance of multifaceted approaches in infection control: A practical experience from an outbreak investigation. PLoS One 2016;11:e0157981. [Crossref]

11. Chipolombwe J, Török ME, Mbelle N, Nyasulu P. Methicillin resistant Staphylococcus aureus multiple sites surveillance: A systemic review of the literature. Infect Drug Resist 2016;9:35-42. [Crossref]

12. Song X, Cheung S, Klontz K, Short B, Campos J, Singh N. A stepwise approach to control an outbreak and ongoing transmission of methicillin-resistant Staphylococcus aureus in a neonatal intensive care unit. Am J Infect Control 2010;38:607-11. [Crossref]

13. Jernigan JA, Titus MG, Groschel DH, Getchell-White S, Farr BM. Effectiveness of contact isolation during a hospital outbreak of methicillin-resistant Staphylococcus aureus. Am J Epidemiol 1996;143:496-504. [Crossref]

14. Mutters NT, Heeg K, Späth I, Henny N, Gunther F. Improvement of infection control management by routine molecular evaluation of pathogen clusters. Diagn Microbiol Infect Dis 2017;88:82-7. [Crossref]

15. O'Hara FP, Suaya JA, Ray GT, Baxter R, Brown ML, Mera RM, et al. spa typing and multilocus sequence typing show comparable performance in a macroepidemiologic study of staphylococcus aureus in the United States. Microb Drug Resist 2016;22:88-96. [Crossref]

16. Strommenger B, Kettlitz C, Weniger T, Harmsen D, Friedrich AW, Witte W. Assignment of Staphylococcus isolates to groups by spa typing, SmaI macrorestriction analysis, and multilocus sequence typing. J Clin Microbiol 2006;44:2533-40. [Crossref]

17. Deurenberg RH, Vink C, Kalenic S, Friedrich AW, Bruggeman CA, Stobberingh EE. The molecular evolution of methicillin-resistant Staphylococcus aureus. Clin Microbiol Infect 2007;13:222-35. [Crossref]

18. Bozdoğan B, Yıldız O, Oryasin E, Kırdar S, Gülcü B, Aktepe O, et al. [t030 is the most common spa type among methicillin-resistant Staphylococcus aureus strains isolated from Turkish hospitals]. Mikrobiyol Bul 2013;47:571-81. [Crossref]

19. Alp E, Klaassen CHW, Doganay M, Altoparlak U, Aydın K, Engin A, et al. MRSA genotypes in Turkey: Persistence over 10 years of a single clone of ST239. J Infect 2009;58:433-8. [Crossref]

20. Kırca Yulmaz S, Acuner IC, Strommenger B, Bek Y, Witte W. [Infectivity-resistotype-genotype clustering of methicillin-resistant Staphylococcus aureus strains in the Central Blacksea Region of Turkey]. Mikrobiyol Bul 2014;48:14-27.

21. Oksuz L, Dupieux C, Tristan A, Bes M, Etienne J, Gurler N. The high diversity of MRSA clones detected in a university hospital in İstanbul. Int J Med Sci 2013;10:1740-5. [Crossref]

22. Deurenberg RH, Stobberingh EE. The molecular evolution of hospital- and community-associated methicillin-resistant Staphylococcus aureus. Curr Mol Med 2009;9:10015. [Crossref]

23. Yamamoto T, Takano T, Higuchi W, Iwao Y, Singur O, Reva I, et al. Comparative genomics and drug resistance of a geographic variant of ST239 methicillin-resistant Staphylococcus aureus emerged in Russia. PLoS One 2012;7:e29187. doi:10.1371/ journal.pone.0029187 [Crossref] 
24. Hong X, Qin J, Li T, Dai Y, Wang Y, Liu Q, et al. Staphylococcal protein a promotes colonization and immune evasion of the epidemic healthcare-associated MRSA ST239. Front Microbiol 2016;7:951. doi:10.3389/fmicb.2016.00951 [Crossref]

25. Otto M. How colonization factors are linked to outbreaks of methicillin-resistant Staphylococcus aureus: The roles of SasX and ACME. Biomol Concepts 2013;4:5337. [Crossref]

26. Sabat AJ, Köck R, Akkerboom V, Hendrix R, Skov RL, Becker K, et al. Novel organization of the arginine catabolic mobile element and staphylococcal cassette chromo- some mec composite island and its horizontal transfer between distinct Staphylococcus aureus genotypes. Antimicrob Agents Chemother 2013;57:5774-7. [Crossref]

27. Senn L, Clerc O, Zanetti G, Basset P, Prod'hom G, Gordon NC, et al. The stealthy superbug: The role of asymptomatic enteric carriage in maintaining a long-term hospital outbreak of ST228 methicillin-resistant Staphylococcus aureus. mBio 2016; 7:e203902015. [Crossref]

28. Teo J, Tan TY, Hon PY, Lee W, Koh TH, Krishnan P, et al. ST22 and ST239 MRSA duopoly in Singaporean hospitals: 2006-2010. Epidemiol Infect 2013;141:153-7. [Crossref] 